\title{
COMPARATIVE ANALYSIS OF NUMERICAL SIMULATION RESULTS OF WORK OF BIAXIALLY BENDED REINFORCED CONCRETE BEAMS WITH EXPERIMENTAL DATA
}

\author{
Pavlikov A.M., ScD, Professor, \\ am.pavlikov@gmail.com, ORCID: 0000-0002-5654-5849 \\ Harkava O.V., PhD, Associate Professor, \\ olga-boiko@ukr.net, ORCID: 0000-0003-2214-3128 \\ Hasenko A.V., PhD, Associate Professor, \\ gasentk@gmail.com, ORCID: 0000-0003-1045-8077 \\ Andriiets K.I., Student, \\ kate.andriec@gmail.com \\ Poltava National Technical Yuri Kondratyuk University
}

\begin{abstract}
The wide distribution of elements of reinforced concrete structures operating in biaxial bending conditions requires a comprehensive theoretical and experimental study of their work. At the present stage, in order to find out the real work of biaxially bended elements, it is necessary to determine all parameters that can affect the fracture pattern of such elements. Comparisons of the numerical modelling results of the work of biaxially bended elements with experimental data are not enough in the literature. Therefore, an important task is to carry out a numerical simulation of the work of biaxially bended reinforced concrete beams in order to compare its results with experimental data and to give recommendations on the possibility and advisability of such modelling for practical use.

15 samples of rectangular reinforced concrete beams made of heavy-weight concrete were used for experimental and numerical studies. The experimental beams were tested for biaxial pure bending at various inclination angles of the external load plane. Carrying out numerical calculations by the finite element method using a PC made it possible to obtain graphs of the distribution of strains and stresses about the principal axes on the surface of the models, as well as in reinforcing bars, and their numerical values with an indication of the extrema. The position of the neutral axis and its change during the loading of sample models were experimentally and numerically studied.

As a result of the study, it was determined that finite-element modelling of the work of biaxially bended beams allows to take into account the features of the exhaustion of their bearing capacity. The computational models of beams adopted during the simulation are adequate in the software package and correspond to real designs. The considered numerical model of reinforced concrete biaxially bended beam is quite simple and allows studying the stress-strain state at different percentages of reinforcement and at different inclination angles of external load plane.
\end{abstract}

Keywords: reinforced concrete, beam, biaxial bending, experiment, numerical simulation.

Introduction. Elements of reinforced concrete structures operating in biaxial bending conditions in which the plane of external loads action does not coincide with the planes of the main axes of inertia of the section include: precast concrete girders, which are rested on the upper belts of trusses and roof beams with two sloping surfaces; crane beams; horizontal elements of outer walls of frame buildings, side elements of shells; elements of bridges and underground structures; supports and girders of transport galleries, overpasses and pipelines; foundation and framing beams used in seismic areas and complex geological conditions; other structures or their elements.

Moreover, as practice shows, biaxial bending arises due to technological inaccuracies in the manufacture, assembling or strengthening of structures; displacement of the main reinforcement from its design position; local destruction of reinforced concrete structures and uneven temperature effects. 
Such wide distribution of elements of reinforced concrete structures operating in biaxial bending conditions requires a comprehensive theoretical and experimental study of their work. The accumulation of experimental data and it comparison with the results of numerical simulation will allow to take into account the peculiarities of the work of elements in biaxial bending and to make recommendations for improvement of the method of their calculation.

Analysis of the latest sources of research and publications in which the solution to the problem has been begun. The works $[1-7]$ are devoted to experimental studies of strength in the normal section of reinforced concrete elements operating in biaxial bending conditions. Most of them focused on determining the destructive load. But the parameters of the deformation mode: $x-$ the neutral axis depth, $\theta$ - the angle of neutral axis inclination, $\varepsilon_{c(1)}$ - the maximum strain of the concrete in the most compressed rib of the beam and the nature of their changes during loading has not been sufficiently investigated. At the present stage, it is necessary to determine all the parameters that can influence the Figure of the destruction of such elements in order to find out the real work of elements operating in biaxial bending conditions. In experimental studies [6 - 7] the focus has been on defining and comparing characteristic parameters of the stress-strain state of elements operating in biaxial bending conditions with the designed. Different cross-sectional shapes of beams operating in biaxial bending conditions and different forms of the compressed concrete zone were considered.

The identification of previously unsolved parts of the general problem to which the article is devoted. The comparative analysis of the results of analytical calculations with the experimental data of the mentioned publications testifies to the convergence of the data. However, the using of analytical methods for calculating the strength of elements operating in biaxial bending conditions involves some complications, namely, the necessity to consider each case of the position of the neutral axis separately and pre-determine the shape of the compressed concrete area [8-10].

Numerical methods of calculation allow to approach the problem of calculation more widely and to consider arbitrary forms of the compressed concrete area in the general formulation [11 - 12]. At the same time, comparisons of the results of numerical simulation of biaxially bended elements work with the experimental data in order to determine the feasibility of its use for calculating the strength of such structures are currently scarce in the literature. This is due to the complexity of implementation of numerical simulation of stress-strain state of elements under complex deformation.

The problem statement is to perform numerical modelling of reinforced concrete beams work operating in biaxial bending conditions in order to compare its results with the experimental data and to provide recommendations on the possibility and feasibility of such modelling for practical application.

Materials or methodology of research. 15 samples of reinforced concrete beams of rectangular profile made of heavy concrete were investigated (Fig. 1).

The tested beams are divided into four series, depending on the number and placement of the principal longitudinal reinforcement. The design of the experimental specimens, the geometric dimensions, the reinforcement and the loading diagram are shown in Figure 1. The characteristics of the concrete and reinforcement, which were used for the experimental beams, are given in Table 1.

Experimental studies were carried out on a special plant with a capacity of $100 \mathrm{kN}$, which provides the possibility of beams supporting and applying loads to them according to a given scheme. This plant allowed to test specimens of the beam at any values of the angle $\beta$ of inclination of the load plane and to conduct stress-test with a fault of not more than 5\%.

The influence of the angle $\beta$ of inclination of the external load plane to the vertical axis of inertia of the section, the number and arrangement of the principal reinforcement on the strength of the beams, the position of the neutral axis in the normal section, and the fibre strain of the concrete compressed area were studied during the experimental testing of the beams. 


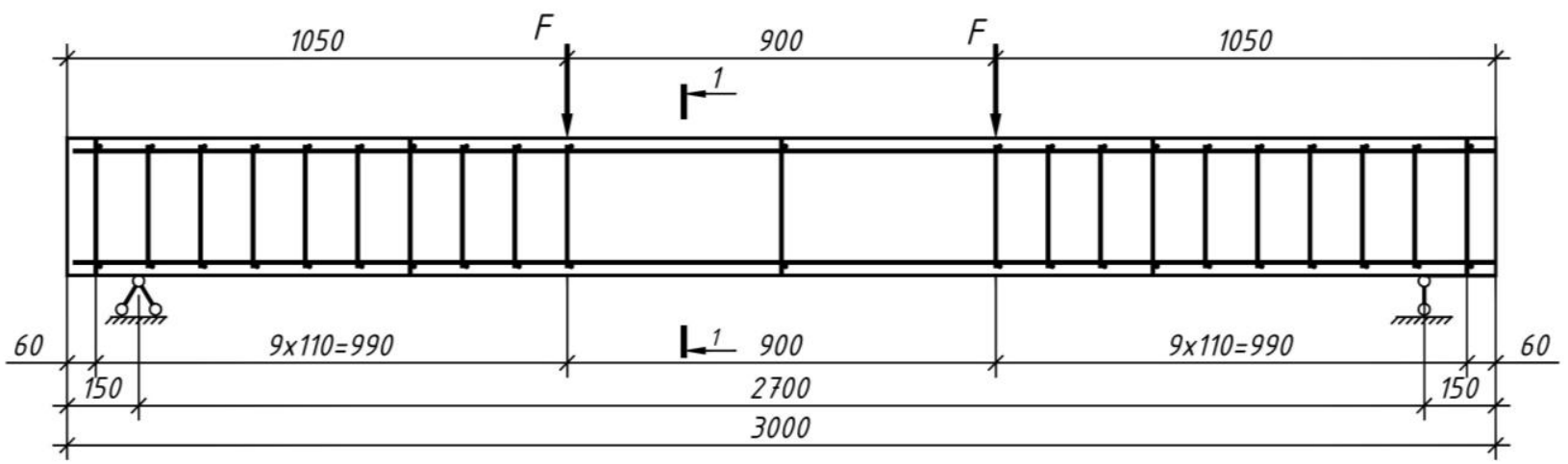

$B R-1(B R-2)$

1-1

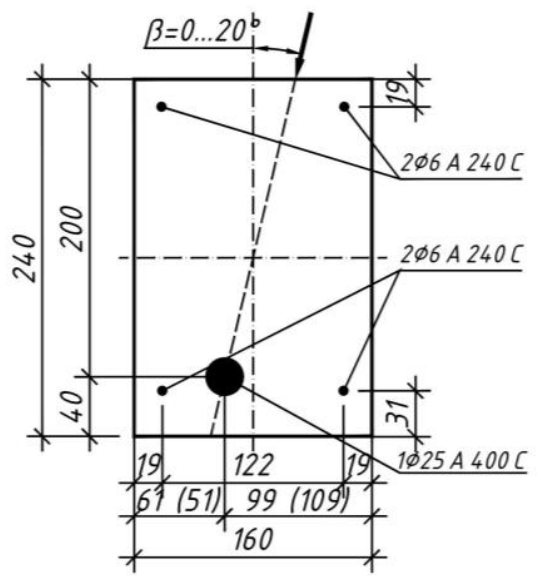

$B R-3$

1-1

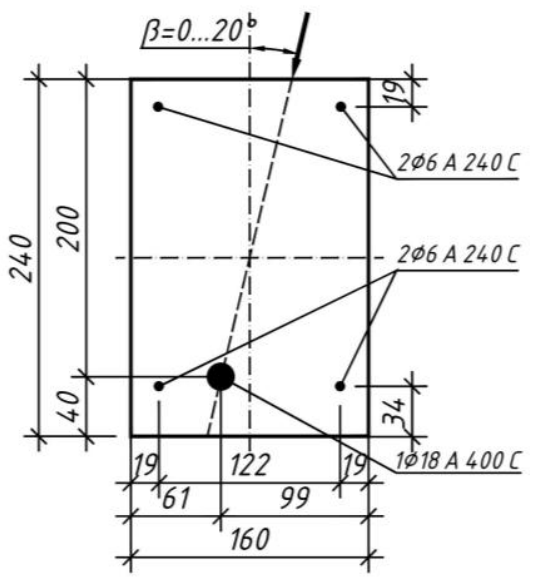

BR-4

1-1

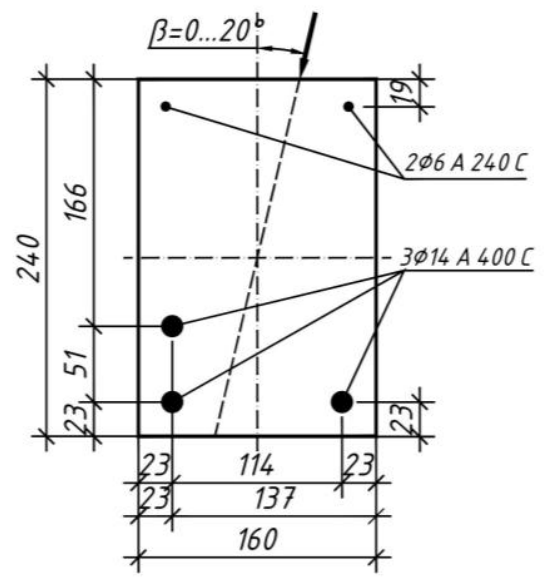

Fig. 1. Design of experimental specimens and loading scheme

Table 1 - Characteristics of experimental beam specimens

\begin{tabular}{|c|c|c|c|c|c|c|c|c|c|}
\hline \multirow{3}{*}{$\begin{array}{l}\text { Code of } \\
\text { speci- } \\
\text { mens }\end{array}$} & \multirow{3}{*}{$\begin{array}{c}\text { Angle of } \\
\text { load plane } \\
\text { inclination, } \\
\beta^{o}\end{array}$} & \multirow{2}{*}{\multicolumn{2}{|c|}{$\begin{array}{c}\text { Characteristics of } \\
\text { concrete }\end{array}$}} & \multicolumn{6}{|c|}{ Characteristics of longitudinal reinforcement } \\
\hline & & & & \multicolumn{3}{|c|}{ principal reinforcement } & \multicolumn{3}{|c|}{ structural reinforcement } \\
\hline & & $\begin{array}{l}f_{\text {cm,prism }}, \\
\mathrm{MPa}\end{array}$ & $\begin{array}{l}E_{c m} \\
\mathrm{MPa}\end{array}$ & $\begin{array}{l}\text { diameter, } \\
\text { class }\end{array}$ & $\begin{array}{l}f_{y k}, \\
\mathrm{MPa}\end{array}$ & $\begin{array}{c}E_{S}, \\
\mathrm{MPa}\end{array}$ & $\begin{array}{l}\text { diameter, } \\
\text { class }\end{array}$ & $\begin{array}{l}f_{y k} \\
\mathrm{MPa}\end{array}$ & $\begin{array}{l}E_{s} \\
\mathrm{MPa}\end{array}$ \\
\hline BR-1-1 & 0 & 25 & 24734 & $1 \varnothing 25 \mathrm{~A} 400 \mathrm{C}$ & 379 & 200000 & $4 \varnothing 6 \mathrm{~A} 240 \mathrm{C}$ & 357 & 200000 \\
\hline $\mathrm{BR}$ & & 5 & 34 & $\mathrm{C}$ & 379 & 0000 & $\mathrm{C}$ & 357 & 0 \\
\hline BR-1-3 & 10 & 25 & 24734 & $1 \varnothing 25 \mathrm{~A} 400 \mathrm{C}$ & 379 & 200000 & $406 \mathrm{~A} 240 \mathrm{C}$ & 357 & 00000 \\
\hline BR-1-4 & 36 & 25 & 24734 & $1 \varnothing 25 \mathrm{~A} 400 \mathrm{C}$ & 379 & 200000 & $4 \varnothing 6 \mathrm{~A} 240 \mathrm{C}$ & 357 & 00000 \\
\hline BR-1-5 & 20 & 22 & 23576 & $1 \varnothing 25 \mathrm{~A} 400 \mathrm{C}$ & 379 & 200000 & $406 \mathrm{~A} 240 \mathrm{C}$ & 357 & 200000 \\
\hline $\mathrm{BR}$ & 13 & 14 & 992 & $1 \varnothing 25 \mathrm{~A} 400 \mathrm{C}$ & 379 & 200000 & $406 \mathrm{~A}$ & 357 & 00000 \\
\hline BR-2-2 & 20 & 14 & 17992 & $1 \varnothing 25 \mathrm{~A} 400 \mathrm{C}$ & 379 & 200000 & $406 \mathrm{~A} 240 \mathrm{C}$ & 357 & 200000 \\
\hline BR-3-1 & 0 & 22 & 23576 & $1 \varnothing 18$ A400C & 542 & 200000 & $406 \mathrm{~A} 240 \mathrm{C}$ & 357 & 200000 \\
\hline BR-3-2 & 3,36 & 22 & 23576 & $1 \varnothing 18 \mathrm{~A} 400 \mathrm{C}$ & 542 & 200000 & $406 \mathrm{~A} 240 \mathrm{C}$ & 357 & 200000 \\
\hline BR-3-3 & 20 & 22 & 23576 & $1 \varnothing 18$ A400C & 542 & 200000 & $406 \mathrm{~A} 240 \mathrm{C}$ & 357 & 200000 \\
\hline BR-4-1 & 0 & 21 & 20921 & $3 \varnothing 14$ A400C & 581 & 200000 & $206 \mathrm{~A} 240 \mathrm{C}$ & 357 & 200000 \\
\hline BR-4-2 & 6,40 & 21 & 20921 & 3014 A400C & 581 & 200000 & $206 \mathrm{~A} 240 \mathrm{C}$ & 357 & 200000 \\
\hline BR-4-3 & 10 & 21 & 20921 & 3014 A400C & 581 & 200000 & $206 \mathrm{~A} 240 \mathrm{C}$ & 357 & 200000 \\
\hline BR-4-4 & 13,36 & 21 & 20921 & 3014 A400C & 581 & 200000 & $206 \mathrm{~A} 240 \mathrm{C}$ & 357 & 200000 \\
\hline BR-4-5 & 20 & 14 & 17992 & 3014 A400C & 581 & 200000 & $206 \mathrm{~A} 240 \mathrm{C}$ & 357 & 200000 \\
\hline
\end{tabular}


Basic material and results. According to the results of observations of flexometer indications during the experiment, it was found that since the beginning of loading the deflections of the test beams increased in mutually perpendicular directions. That is, the cross section was moved in the direction of both axes of the section symmetry. The correlation between the projections of the total deflection $f_{X} / f_{Y}$ on the $X$ and $Y$ axes, respectively, increased as the angle of inclination $\beta$ of the load plane increased.

In the experimental tests, beams with both one and three discretely located principal reinforcing bars were investigated. In the samples of the BR-1 and BR-3 series, the principal bar was located at a point with the coordinates of the bars gravity centre of the BR-4 beams. Therefore, provided that at the time of destruction all the bars in the tensile area reach the yield strength, the centre of gravity of the reinforcing bars coincides with the point of application of the resultant force in these bars. That is, the points of application of resultant forces in the tension area of beams of series BR-1, BR-3 and BR-4 coincide. During the tests, it was noted that the nature of the formation and crack growth, the increase of deflections, the settling of the supports and the direct destruction of the beams in series BR-1 with single reinforcement and beams BR-4 which reinforced by three bars in the tension area, at the same angles $\beta$ did not differ.

It should be noted that due to the displacement of the principal reinforcement from the axis of symmetry of the normal section of all experimental beams, axially symmetric loading at $\beta=0^{0}$ caused the phenomenon of provoked biaxial bending of the test beams (BR-1-1, BR-3-1, BR-4-1) (Fig. 2, $b$ ).

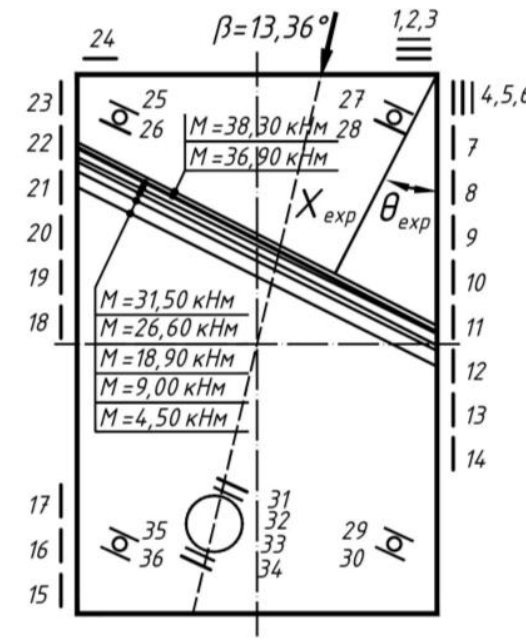

BR-1-4

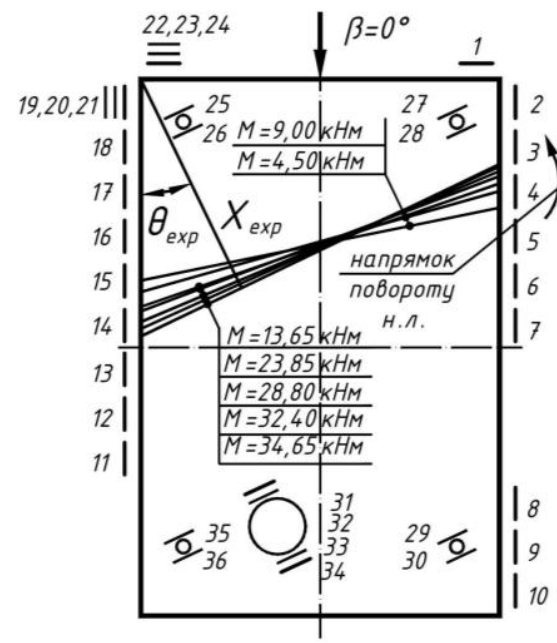

BR-1-1

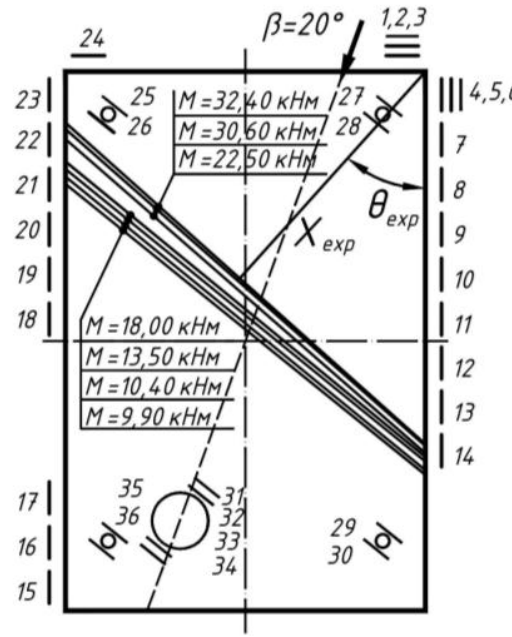

BR-2-2

a)

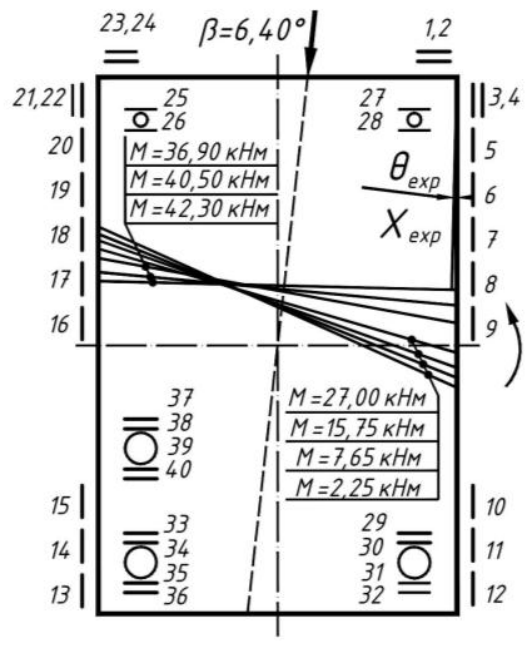

BR-4-2

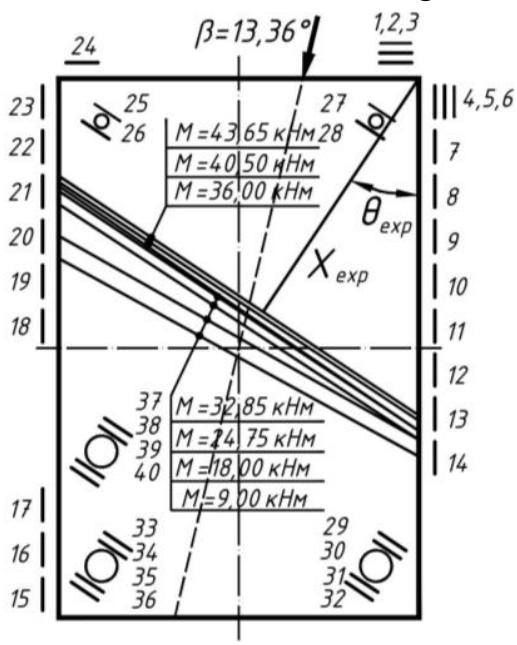

BR-4-4

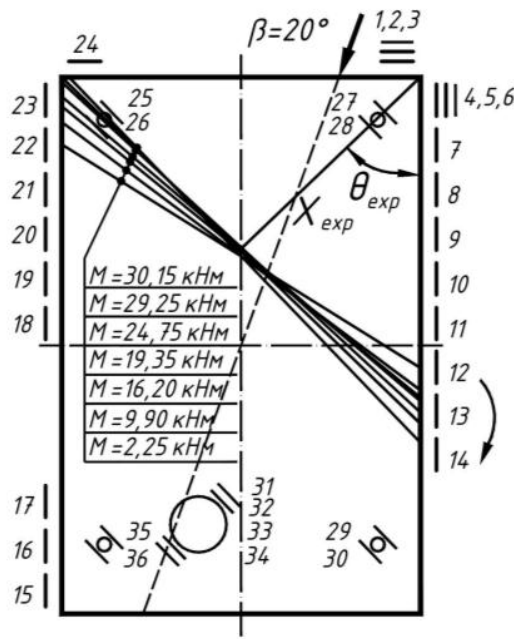

BR 1-5

b)

Fig. 2. Changing the neutral axis position during the loading process: $a$-parallel movement; $b$ - rotation 
Increasing the angle $\beta$ to $6,40^{\circ}$ (BR-1-2, BR-4-2) (Fig. 2, b) made it possible to obtain a separate case of biaxial bending - an analog of simple bending in which the form of the compressed area of concrete was rectangular. A further increase in the angle $\beta$, on the contrary, caused a biaxial bending, but with a deflection in the other direction. During the tests, this could easily be observed by following the flexometer indicator movement.

In the study of beams which operating in biaxial bending conditions, special attention was paid to the determination of the neutral axis position, since it is an important criterion for the deflection mode of the beam elements. From Fig. 2, $a$ it is seen that in the beams BR-1-4, BR-2-2, BR-3-2 and BR-4-4 during the entire loading the neutral axis was a parallel moved toward the most compressed rib. The plane of the external load passed through the point of application of the resultant force in the principal reinforcement.

In all other beams, a neutral axis rotation was observed in the loading process (Fig. 2, $b$ ). Moreover, its direction depended on the location of the load plane relative to the point of application of the resultant in the principal reinforcement. In the case of loading at a small angle $\beta$, that is, when the load plane was passing to the right of the resultant force application point in the principal reinforcement, the neutral axis rotated counter-clockwise as the load increased (Fig. 2, $b$ BR-1-1, BR-4-2). The rotation of the neutral line clockwise occurred at the plane location of the external load action to the left of the point of application of the resultant in the principal reinforcement (Fig. 2, $b$ BR-1-5).

In view of the computer technology development and its wide technical capabilities, it is convenient to study the stress-strain state of building structures as a whole and its individual members using computer-aided finite element analysis programs. Therefore, it is decided to repeat the experimental investigation by numerically simulating the work of similar samples. The numerical simulation of the stress-strain state of structures was performed on the NASTRAN system. A training demo version of SDRC-FEMAP 8 / 1a S / N 000-00-00-DEMO-406F-00000000 was used. The finite element model (Fig. 3) of the investigated structures and the subsequent finite element analysis were performed according to the algorithm shown on Figure 4.

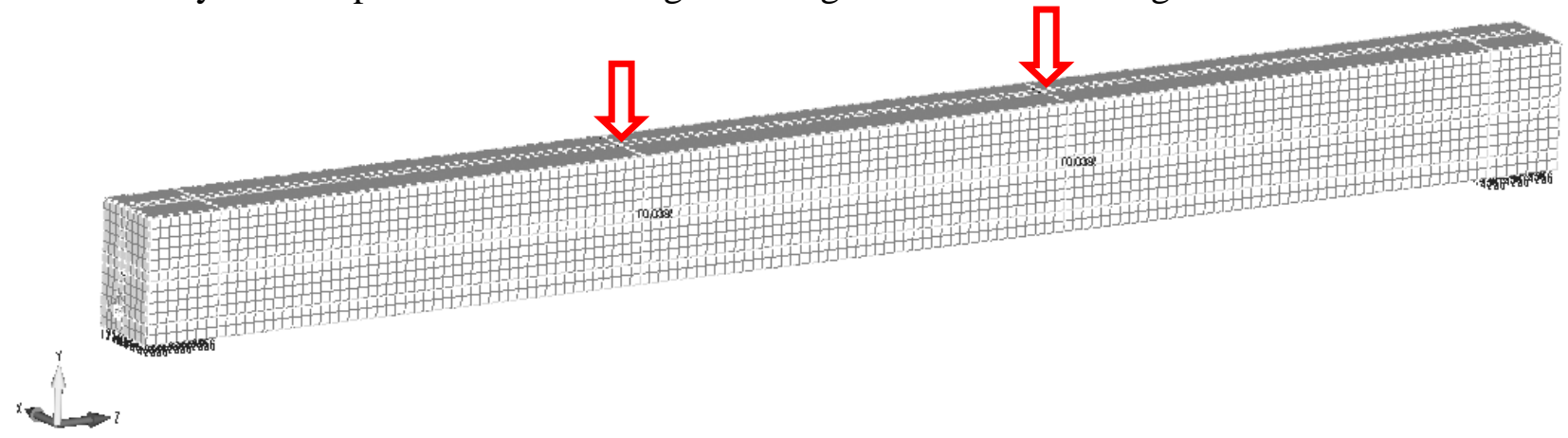

Fig. 3. Finite element model of the studied samples

\begin{tabular}{|c|c|c|}
\hline No item & & The name of the action \\
\hline 1 & $\rightarrow$ & Development of spatial geometry of construction \\
\hline 2 & $\rightarrow$ & $\begin{array}{c}\text { Specification of physical and mechanical characteristics of materials (initial } \\
\text { modulus of elasticity and Poisson's ratio, full stress-strain diagrams) }\end{array}$ \\
\hline 3 & $\rightarrow$ & Specify the properties of materials (linear, flat or spatial) \\
\hline 4 & $\rightarrow$ & Choosing the type and size of finite elements, their optimization \\
\hline 5 & $\rightarrow$ & Splitting the model into finite elements, validating the model \\
\hline 6 & $\rightarrow$ & Application of external loading and boundary conditions \\
\hline 7 & $\rightarrow$ & $\begin{array}{c}\text { Choice of type (linear or nonlinear, strength or stability calculation, static or } \\
\text { dynamic, etc.) and finite element calculation; analysis of the results obtained }\end{array}$ \\
\hline
\end{tabular}

Fig. 4. An algorithm for creating a finite element model and performing an analysis 
Numerical calculations by the finite element method with the use of a computer made it possible to obtain graphs of strains and stresses distribution (Table 2) about the principal axes on the surface of the models, in the reinforcing bars and their numerical values with the indication of extrema.

Table 2 - Results of finite element study of sample models

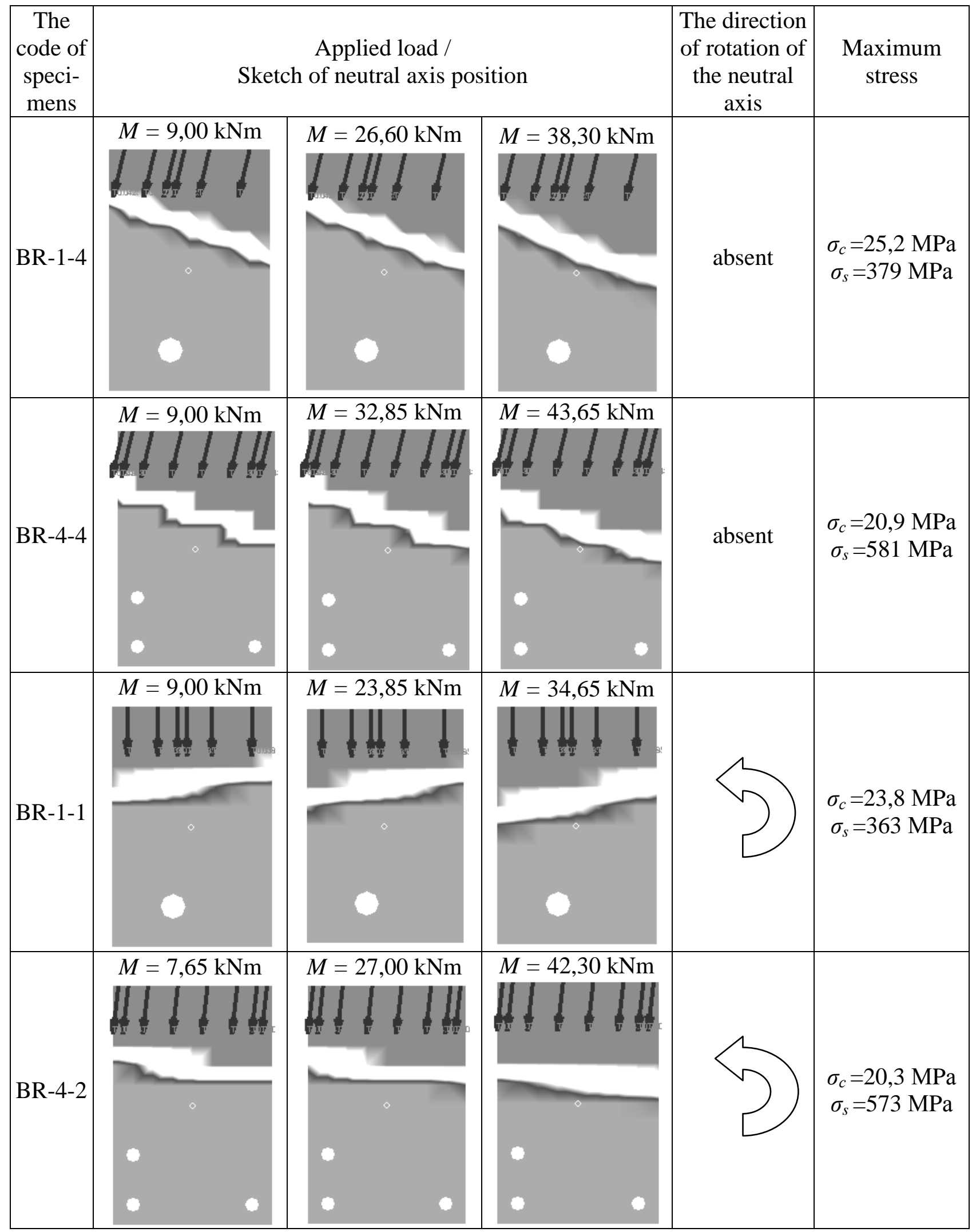


The materials of the model - steel reinforcement and concrete - were assigned separately as isotropic. The values of the physical and mechanical characteristics of the materials (modulus of elasticity and the Poisson`s ratio) and the stress-strain dependence $\sigma-\varepsilon$ were taken in accordance with the current norms for the design of reinforced concrete structures. It was assumed that stress distribution in concrete is described by a fractional-rational function.

A detailed analysis of stress concentration places is performed. The position of the neutral axis and its change in the process of loading the model samples are identical to the results of the experiment (Table 2), which indicates that the created model corresponds to the actual operation of the beam in biaxial bending conditions.

The value of the maximum stresses in materials at the experimental value of the destructive bending moment (Table 2) determined with the help of a PC coincide with the corresponding strength characteristics of the test samples (Table 1).

Conclusions. As a result of the research, it was determined that the finite element modelling of the work of biaxially bended beams on the PC allows to take into account the peculiarities of their carrying capacity loss. The design beam models in the software complex adopted during the simulation are adequate and correspond to real constructions. The considered numerical model of reinforced concrete beam which operating in biaxial bending conditions is quite simple and allows studying the stress-strain state at different reinforcement ratio and at different angles $\beta$ of the inclination of the external load plane. The use of a computer program to simulate the stress-strain state of a normal cross-section of a beam which operating in biaxial bending conditions allow to follow changings of position of the neutral axis during loading. Computer modelling also makes it possible to plan experimental studies and optimize the number and size of samples for testing, to allocate places in the samples that need special attention during the experiment.

\section{References}

[1] M.S. Torjanik, "Jeksperimental'nye issledovanija i raschet po stadii razrushenija zhelezobetonnyh stoek, rabotajushhih na central'noe szhatie i kosoj izgib", Nauchnye zapiski Poltavskogo instituta inzhenerov sel'skohozjajstvennogo stroitel'stva, Poltava, Vyp. 1, pp. 40, 1940.

[2] N.I. Smolin, Kosoj izgib zhelezobetonnyh balok: Trudy Gor'kovskogo inzhenernostroitel'nogo instituta. Gor'kij, 1951.

[3] L.I. Serdjuk, Jeksperimental'no-teoreticheskie issledovanija prochnosti obychnyh i predvaritel'no-naprjazhennyh zhelezobetonnyh jelementov prjamougol'nogo, tavrovogo i Gobraznogo sechenij so sterzhnevoj armaturoj pri kosom izgibe, Poltava, 1966.

[4] A.N. Pavlikov, Jeksperimental'no-teoreticheskie issledovanija prochnosti, deformativnosti, obrazovanija i raskrytija treshhin po sechenijam normal'nym k prodol'noj osi kosoizgibaemyh keramzitobetonnyh jelementov, K., 1980.

[5] O.V. Zerniuk, Napruzheno-deformovanyi stan zalizobetonnykh elementiv tavrovoho profiliu pry kosomu zghyni vid dii ekspluatatsiinykh rivniv navantazhen, Poltava, 1997.

[6] Ye.V. Diachenko, Rozrakhunok mitsnosti kosozihnutykh zalizobetonnykh elementiv z urakhuvanniam povnoi diahramy fizychnoho stanu betonu, Poltava, 2006.

[7] A.M. Pavlikov, Neliniina model napruzheno-deformovanoho stanu kosozavantazhenykh zalizobetonnykh elementiv u zakrytychnii stadii, Poltava, 2007.

[8] A.M. Pavlikov, O.V. Harkava, B.A. Baryliak, Yu.O. Prykhodko, "Rozrakhunok mitsnosti na kose zghynannia zalizobetonnykh elementiv tavrovoho profiliu za sproshchenoiu deformatsiinoiu modelliu", Zbirnyk naukovykh prats (resursoekonomni materialy, konstruktsii, budivli ta sporudy), Rivne: NUVHP, Vol. 36, pp. 151 - 157, 2018.

[9] A.M. Pavlikov, O.V. Harkava, Zalizobetonni konstruktsii v umovakh skladnoho deformuvannia ta yikh rozrakhunok, Poltava: PoltNTU, 2018.

[10] A.V. Hasenko, I.A. Yurko, O.G. Fenko, P.A. Yurko, "Causes of the eccentric compression 
reinforced concrete elements fixed joint stanchion and rafter gable frame of agricultural buildings", The International Scientific Periodical Journal "Modern Technology and Innovative Technologies", Germany: Karlsruhe, Issue no. 2, Vol. 2, pp. 126 - 129, 2017. DOI: $10.21893 / 2567-5273.2017-02-02-033$

[11] A.V. Hasenko, O.P. Novytskyi, "Numerical experiment for the determination of the stressstrain condition of the system "Basis - Vibroreinforced soil-cement pile", International Journal of Engineering \& Technology: Publisher of International Academic Journals, Vol 7, no. 4.8 (2018), Special Issue 8, Science Publishing Corporation, RAK Free Trade Zone, pp. $41-47,2018$. DOI: 10.14419/ijet.v7i4.8.27211

[12] A.V. Hasenko, I.A. Yurko, P.A. Yurko, L.V. Hasenko, "Skinchenno-elementnyi rozrakhunok pozatsentrovo-stysnutykh sterzhniv pry proektuvanni zalizobetonnykh konstruktsii inzhenernykh sporud", Mosty ta tuneli: teoriia doslidzhennia, praktyka : $z b$. nauk. pr. DNUZT imeni akademika V. Lazariana, Dnipropetrovsk, Vol. 13, pp. 4-11, 2018. DOI: $10.15802 /$ bttrp2018/151059.

\title{
ПОРІВНЯЛЬНИЙ АНАЛІЗ РЕЗУЛЬТАТІВ ЧИСЕЛЬНОГО МОДЕЛЮВАННЯ РОБОТИ КОСОЗІГНУТИХ ЗАЛІЗОБЕТОННИХ БАЛОК 3 ЕКСПЕРИМЕНТАЛЬНИМИ ДАНИМИ
}

\author{
Павліков А.М., д.т.н, професор, \\ am.pavlikov@gmail.com, ORCID: 0000-0002-5654-5849 \\ Гарькава О.В., к.т.н, \\ olga-boiko@ukr.net, ORCID: 0000-0003-2214-3128 \\ Гасенко А.В., к.т.н., доцент, \\ gasentk@gmail.com, ORCID: 0000-0003-1045-8077
}

Андрієць К.I., студентка, kate.andriec@gmail.com Полтавський начіональний технічний університет імені Юрія Кондратюка

\begin{abstract}
Анотація. Широке застосування елементів залізобетонних конструкцій, що працюють в умовах косого згину, вимагає всебічного теоретичного та експериментального дослідження їх роботи. На даному етапі для з'ясування реальної роботи косозігнутих елементів необхідне визначення всіх параметрів, які можуть впливати на картину руйнування таких елементів. Даних порівнянь результатів чисельного моделювання роботи косозігнутих елементів 3 експериментальними даними поки в літературі недостатньо. Тому, важливим завданням $\epsilon$ виконання чисельного моделювання роботи косозігнутих залізобетонних балок з метою порівняння його результатів з експериментальними даними і рекомендації щодо можливості і доцільності такого моделювання для практичного застосування.

Для експериментального і чисельного дослідження використовувалися 15 зразків залізобетонних балок прямокутного профілю 3 важкого бетону. Досліджувані балки випробовувалися на косий чистий згин при різних кутах нахилу зовнішньої силової площини. Проведення чисельних розрахунків методом скінченних елементів 3 використанням ПК дозволило отримати графіки розподілу деформацій і напружень відносно головних осей на поверхні моделей, а також в арматурних стержнях і їх числові значення зі зазначенням екстремумів. Експериментально і чисельно досліджено положення нейтральної лінії і його зміна в процесі завантаження моделей зразків.

В результаті проведення дослідження визначено, що скінченно-елементне моделювання роботи косозігнутих балок дозволяє врахувати особливості вичерпання їх несучої здатності. Прийняті під час проведення моделювання розрахункові моделі балок в програмному комплексі адекватні та відповідають реальним конструкціям. Розроблена чисельна модель залізобетонної косозігнутої балки досить проста і дозволяє проводити
\end{abstract}


дослідження напружено-деформованого стану при різних відсотках армування і при різних кутах нахилу зовнішньої силової площини.

Ключові слова: залізобетон, балка, косий згин, експеримент, чисельне моделювання.

\title{
СРАВНИТЕЛЬНЫЙ АНАЛИЗ РЕЗУЛЬТАТОВ \\ ЧИСЛЕННОГО МОДЕЛИРОВАНИЯ РАБОТЫ КОСОИЗГИБАЕМЫХ ЖЕЛЕЗОБЕТОННЫХ БАЛОК С ЭКСПЕРИМЕНТАЛЬНЫМИ ДАННЫМИ
}

\author{
Павликов А.Н., д.Т.н, профессор, \\ am.pavlikov@gmail.com, ORCID: 0000-0002-5654-5849 \\ Гарькавая О.В., к.Т.н, \\ olga-boiko@ukr.net, ORCID: 0000-0003-2214-3128 \\ Гасенко А.В., к.т.н., доцент, \\ gasentk@gmail.com, ORCID: 0000-0003-1045-8077
}

Андриец К.И., студентка, kate.andriec@gmail.com Полтавский начиональный технический университет имени Юрия Кондратюка

\begin{abstract}
Аннотация. Широкое распространение элементов железобетонных конструкций, работающих в условиях косого изгиба, требует всестороннего теоретического и экспериментального исследования их работы. На современном этапе для выяснения реальной работы косоизгибаемых элементов необходимо определение всех параметров, которые могут влиять на картину разрушения таких элементов. Данных сравнений результатов численного моделирования работы косоизгибаемых элементов с экспериментальными данными пока в литературе недостаточно. Поэтому, важной задачей является выполнение численного моделирования работы косоизгибаемых железобетонных балок с целью сравнения его результатов с экспериментальными данными и рекомендации о возможности и целесообразности такого моделирования для практического применения.

Для экспериментального и численного исследования использовались 15 образцов железобетонных балок прямоугольного профиля из тяжелого бетона. Опытные балки испытывались на косой чистый изгиб при различных углах наклона внешней силовой плоскости. Проведение численных расчетов методом конечных элементов с использованием ПК позволило получить графики распределения деформаций и напряжений относительно главных осей на поверхности моделей, а также в арматурных стержнях и их числовые значения с указанием экстремумов. Экспериментально и численно исследовано положение нулевой линии и его изменение в процессе загружения моделей образцов.

В результате проведения исследования определено, что конечно-элементное моделирование работы косоизгибаемых балок позволяет учесть особенности исчерпания их несущей способности. Принятые во время проведения моделирования расчетные модели балок в программном комплексе адекватные и соответствуют реальным конструкциям. Рассматриваемая численная модель железобетонной косоизгибаемой балки достаточно проста и позволяет проводить исследования напряженно-деформированного состояния при различных процентах армирования и при различных углах наклона внешней силовой плоскости.
\end{abstract}

Ключевые слова: железобетон, балка, косой изгиб, эксперимент, численное моделирование. 